\title{
Density and rheology of acid suspensions of peanut waste in different conditions: An engineering basis for bioethanol production
}

\author{
T.C. Polachini ${ }^{\text {a,* }}$, A.C.K. Sato ${ }^{\text {b }}$, R.L. Cunha ${ }^{\text {b }}$, J. Telis-Romero ${ }^{\text {a }}$ \\ a Food Engineering and Technology Department, State University of São Paulo, São José do Rio Preto, São Paulo 15054-000, Brazil \\ b School of Food Engineering, Department of Food Engineering, University of Campinas (UNICAMP), Campinas, São Paulo 13083-862, Brazil
}

\section{A R T I C L E I N F O}

\section{Article history:}

Received 25 August 2015

Accepted 10 February 2016

Available online 11 February 2016

\section{Keywords:}

Rheological parameter

Peanut shell

Physical properties

Shear thinning

Suspension

Bioethanol

\begin{abstract}
A B S T R A C T
The current world-wide energetic situation implies in researches about new resources and technologies capable of producing biofuels, such as the peanut processing residues. To design operations associated to bioethanol processing, understanding material properties, as density and rheology, is necessary. In this study, peanut shells were firstly chemically characterized, showing $37.1 \%$ cellulose, $33.4 \%$ hemicellulose and $15.0 \%$ lignin. Aqueous acid suspensions of powdered peanut shell were prepared and their physical properties were determined. Rheological parameters and density could be correlated with solid content and temperature by exponential and quadratic equations, respectively, while $\mathrm{pH}$ did not present significant effect on these parameters. Dilute suspensions showed Newtonian behavior, but at concentration above $8 \%(w / w)$ of solids, a non-Newtonian behavior was observed, showing yield stress and shear thinning. By evaluating the relative viscosity behavior with increasing solids concentration, Farris effect was also evidenced in suspensions above $8 \%$ of solids due to the presence of fine particles. Such result indicates the possibility of processing peanut shells for biofuel production in solids concentration higher than $10 \%$, without a significant influence on viscosity.
\end{abstract}

(c) 2016 Elsevier B.V. All rights reserved.

\section{Introduction}

Nowadays, with the high exploitation of fossil fuels, one of the biggest environmental worries is the fuel supply [1]. It has influenced many studies to bring new technologies and renewable sources to produce energy, mainly from lignocellulosic materials. Biomass is the more suitable and available source able to produce biofuels, as bioethanol and biodiesel in a short time [2,3].

Agro-industrial residues, wood and some urban residues are the examples of biomass, with a dry matter composed of cellulose, hemicellulose and lignin. Agro-industrial wastes are an interesting biomass source due to its low cost and abundance in agriculture producing countries as Brazil [4].

Currently in Brazil, peanut processing can generate more than 90 thousand tons of waste, considering the average shell/grain ratio of $30 \%$ [5] and an annual production, of around 320,000 tons in 2014 [6]. Thus, its polymeric composition of fermentable material is attractive to develop new treatments and processes. The peanut shells, currently used as fertilizers and fodder in poultry farms, could be used as raw material in bioethanol conversion/preparation processing after physical, chemical, biological or even combined pretreatments.

The major step of bioethanol production consists into the breakdown of hemicellulose and the crystalline structure from the cellulose for sugars

\footnotetext{
* Corresponding author.

E-mail address: tiagopolachini@terra.com.br (T.C. Polachini).
}

release, which will be fermented into ethanol and later distilled. All these steps generally occur in stirred bioreactors using acid medium [7-9].

A correct understanding of the material properties, as density and rheology, is necessary to design cost-effective treatment processes [10] during fermentation and handling agro-industrial residues. Rheology is also used to understand the product's structural behavior [11], besides its importance on designing pipes and process equipment.

Rheological/structural behavior depends on a number of factors, including chemical composition, particle size and shape, surface effects and/or additives presence. These factors are generally heterogeneous in biomass suspensions, once particles vary in terms of composition, size and shape [12]. The flow characteristics of suspensions can be defined both by the continuous or dispersed phase, and even by the influence of one in another [13]. Considering that the combination of these facts makes unique the properties of each suspension, the need of published physical properties data of such systems is emphasized.

So, this study intended to characterize and evaluate the rheological behavior and density of acid suspensions of peanut shell powder in different conditions of biomass concentration, temperature and $\mathrm{pH}$.

\section{Materials and methods}

\subsection{Peanut shell preparation}

Cleaned and dried peanut (Arachis hypogaea L.) shells were obtained from Agro-industrial Cooperative - COPLANA (Jaboticabal, São Paulo, 
Brazil). Using a knife mill MA380 (Marconi, Piracicaba, Brazil), the shells were milled and separated by Tyler sieves (mesh 12 and 24) to obtain a particle size distribution between 1397 and $701 \mu \mathrm{m}$.

\subsection{Chemical characterization}

Analysis of moisture, dry matter, cellulose, hemicelullose, lignin and total sugars were done aiming the characterization of the peanut shell. Moisture and dry matter were determined by a vacuum oven, according to AOAC 926.12 method [14].

Cellulose, hemicellulose and lignin content were determined using a method on reflux extraction with neutral detergent or acid detergent solutions for 90 min $[15,16]$. Filtrate was washed with hot distilled water and ethanol, then oven-dried until constant weight. The percentage of each washing represents the neutral detergent fibers (NDF) and acid detergent fibers (ADF). To determinate the lignin amount, sulfuric acid $(72 \% \mathrm{w} / \mathrm{w})$ was added to the samples under magnetic stirring at $20{ }^{\circ} \mathrm{C}$ every hour, during $3 \mathrm{~h}$. After washing with hot distilled water until a sulfuric acid concentration of $3 \%(w / w)$, the filtration residue (lignin) was dried and weighed. The difference between NDF and ADF indicates the hemicellulose content, and subtracting the lignin percentage from ADF results in the cellulose content.

Total sugars content was determined from the acid hydrolyzed samples of NDF and ADF, by high-performance liquid chromatography (HPLC) according to the AOAC 982.14 method [14]. Hydrolyzed sample was centrifuged at $1850 \times \mathrm{g}$ for $2 \mathrm{~min}$ at $20^{\circ} \mathrm{C}$. After removing the supernatant, sugars were extracted into $50 \%$ ethanol, passed through a SepPak ${ }^{\circledR}$ C18 cartridge (Waters Associates, Milford, MA, USA) and then filtered through a $0.45 \mathrm{~mm}$ nylon disk. Separation and quantification were carried out on a $\mu$ bondapak- $\mathrm{NH}_{2}$ column $(30 \mathrm{~cm} \times 3.9 \mathrm{~mm}$ i.d., Waters, Milford, MA, USA) and a refractive index (IR) detector, using $\mathrm{CH}_{3} \mathrm{CN}$ and $\mathrm{H}_{2} \mathrm{O}$ (80:20 v:v) as mobile phase. Concentrations were calculated based on prepared external standards.

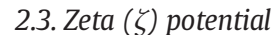

The zeta $(\zeta)$ potential of the suspensions of powdered peanut shells was determined using a Zetasizer Nano ZS equipment (Malvern Instruments, Worcestershire, UK). Suspensions containing $0.01 \%(w / w)$ of powdered peanut shells were previously prepared at different $\mathrm{pH}$ (3.0, 4.0, 5.0, 6.0 and 7.0) using $0.05 \%(w / w) \mathrm{H}_{2} \mathrm{SO}_{4}$ solutions. Each sample was transferred to the cuvettes for zeta potential measurements, which were done in triplicate.

\subsection{Particles size distribution}

Particle size distribution of the peanut powder, separated by Tyler sieves mesh 12 and 24, was evaluated by laser diffraction (LD) using a Mastersizer S model MAM 5005 (Malvern Instruments Ltd., UK), with distilled water as dispersing medium. Each sample was evaluated in 6 replicates. Diameter of samples was represented as the volume weighted mean diameter $\left(D_{4,3}\right)$, defined by Eq. (1) and surface weighted mean diameter $\left(D_{3,2}\right)$, defined by Eq. (2). Polydispersity was evaluated according to span value, given in Eq. (3).

$$
\begin{aligned}
D_{4,3} & =\frac{\sum n_{i} \cdot d_{i}^{4}}{\sum n_{i} \cdot d_{i}^{3}} \\
D_{3,2} & =\frac{\sum n_{i} \cdot d_{i}^{3}}{\sum n_{i} \cdot d_{i}^{2}}
\end{aligned}
$$

$\operatorname{span}=\frac{D_{9,0}-D_{1,0}}{D_{5,0}}$ where, $n_{i}$ is the number of particles with $d_{i}$ diameter, $D_{1,0}, D_{5,0}$ and $D_{9,0}$ are diameters at $10 \%, 50 \%$ and $90 \%$ cumulative volume, respectively.

\subsection{Optical microscopy (OM)}

Particle morphology was analyzed through optical microscopy (OM). Using microscope slides and glass cover slips, particles were observed at 10, 40 and $100 \times$ magnification using a Carl Zeiss Model Axio Scope A.1 (Zeiss, Germany). Images were also evaluated using the public domain software Image J v1.36b. The pixel-scale values were converted into microns by a scaling factor and the group of particles present in the captured images were measured. The length $(L)$ and the width $(w)$ were the dimensions determined for the fibers, and the aspect ratio $\left(a_{r}\right)$ was calculated by $a_{r}=L / w$.

\subsection{Rheological measurements}

Suspensions were prepared with different solids content: 0,$2 ; 4 ; 6$; $8 ; 10$ and $12 \%(w / w)$ using an analytical balance (model AUX220, Shimadzu, Japan). Solutions with varying pH (3.0; 4.0; 5.0; 6.0 and 7.0) were used for dispersing the suspensions. These solutions were prepared and stabilized for 3 days with distilled water and diluted sulfuric acid $\left(\mathrm{H}_{2} \mathrm{SO}_{4}\right)$ at $0.05 \%$. The suspensions were prepared and insert immediately into the equipment.

Rheological measurements were done in a AR-G2 rheometer (TA Instruments, USA) with SPC (Starch Pasting Cell) geometry to avoid the particles sedimentation. Samples of approximately $28 \mathrm{~cm}^{3}$ were required in each run and shear rate ramps were set from 0 to $260.5 \mathrm{~s}^{-1}$ in steady flow. Sample temperature $\left(1,10,20,30,40,50\right.$ and $\left.60{ }^{\circ} \mathrm{C}\right)$ was controlled by the equipment bath. Shear stress data were extracted by data acquisition system Universal Analysis 2000 version 4.7 (TA Instruments, USA).

Chlorobenzene was the standard substance in calibration. The measurements in Table 1 did not present significant difference $\left(p_{\text {value }}>0.050\right)$ with the ones published in literature [17], indicating that the equipment is properly calibrated.

\subsection{Density analysis}

Density $\left(\rho, \mathrm{kg} / \mathrm{m}^{3}\right)$ was determined for the same suspensions used in rheological determination. Analyses were carried out in a volumetric standard picnometer DIN ISSO 3507 (Brand, Wertheim, Germany), equipped with a lid and a graduated thermometer with sensibility of $0.1^{\circ} \mathrm{C}$. Sample temperature was changed and stabilized using a thermostatic bath MA-159 (Marconi, São Paulo, Brazil). For each measurement, the picnometer was calibrated with distilled water according to the procedures described in ASTM-D1480 [18].

Experimental measurements were done in triplicate, using a $50 \mathrm{~mL}$ picnometer and an analytical balance with $0.0001 \mathrm{~g}$ of precision (model AUX220, Shimadzu, Japan).

\subsection{Data modeling}

Rheograms were plotted, obtaining shear stress as function of shear rate. Rheological behavior was evaluated using flow models with 1 to 3 parameters (Eqs. (4)-(7b)) and their adjusted correlation coefficient $\left(R^{2}\right)$. Newton (1 parameter), Bingham and Power Law (2 parameters) and Herschel-Bulkley model (3 parameters) are represented by Eqs. (4)-(7b), respectively. Whereas $\tau(\mathrm{Pa})$ is shear stress (Pa), $\dot{\gamma}(1 / \mathrm{s})$ is shear rate, $k\left(\mathrm{~Pa} . \mathrm{s}^{n}\right)$ is the consistency coefficient, $n$ (dimensionless) is the flow behavior index, $\tau_{0}(\mathrm{~Pa})$ is the initial yield stress to start the flow, $\mu$ (Pa.s) is Newtonian viscosity, $\eta_{B}$ (Pa.s) is plastic viscosity and $\eta_{\text {app }}$ (Pa.s) is apparent viscosity at a fixed shear rate $[11,19]$.

$\tau=\mu \dot{\gamma}$ 
Table 1

Viscosity validation using chlorobenzene as standard substance.

\begin{tabular}{|c|c|c|c|c|c|}
\hline \multirow[t]{2}{*}{ Standard substance } & \multirow{2}{*}{$\frac{\text { Temperature }}{{ }^{\circ} \mathrm{C}}$} & \multicolumn{2}{|c|}{ Viscosity (cP) } & \multirow[t]{2}{*}{ Confidence interval (95\%) } & \multirow[t]{2}{*}{$p_{\text {value }}$} \\
\hline & & Literature $^{a}$ & Experimental $^{\mathrm{b}}$ & & \\
\hline \multirow{3}{*}{ Chlorobenzene $\mathrm{C}_{6} \mathrm{H}_{5} \mathrm{Cl}$} & 0 & 1.058 & $1.056 \pm 0.0104$ & $(1.049 ; 1.063)$ & 0.596 \\
\hline & 25 & 0.753 & $0.751 \pm 0.0071$ & $(0.746 ; 0.755)$ & 0.377 \\
\hline & 50 & 0.575 & $0.578 \pm 0.0060$ & $(0.574 ; 0.582)$ & 0.087 \\
\hline
\end{tabular}

a Data from Lide (1993).

b Mean \pm standard deviation for eleven experimental data.

$\tau=\tau_{0}+\eta_{B} \dot{\gamma}$

$\eta_{\text {app }}=\frac{\tau_{0}}{\dot{\gamma}}+\eta_{B}$

$\tau=k \dot{\gamma}^{n}$

$\eta_{a p p}=k \dot{\gamma}^{n-1}$

$\tau=\tau_{0}+k \dot{\gamma}^{n}$

$\eta_{\text {app }}=\frac{\tau_{0}}{\dot{\gamma}}+k \dot{\gamma}^{n-1}$

A usual manner to correlate the rheological parameters with solid content and temperature was proposed by Rao [20]. The author recommends exponential equations to fit data, due to their good representativeness. The following exponential models (Eqs. (8) and (9)) have the adjusted parameters $A, B, C$ and $D$, and $X_{S}$ as the solid content $(\% \mathrm{~m} / \mathrm{m}), T$ as the temperature $\left({ }^{\circ} \mathrm{C}\right)$ and $R$ as the gas universal constant $(8.314 \mathrm{~J} / \mathrm{mol} \mathrm{K})$.

$\mu, \eta_{\text {app }}, k, n=A+B \exp \left(\frac{C}{R(T+273.15)}\right) X_{S}^{D}$

$\mu, \eta_{\text {app }}, k, n=A \exp \left(B X_{S}+C X_{S}^{2}+\frac{D}{R(T+273.15)}\right)$

For suspensions, it is common to use the values of relative viscosity $\left(\eta_{\text {rel }}\right)$ as function of the volume fraction of solids, which is given by a relation between the suspension $\left(\eta_{s}\right)$ and dispersant $\left(\eta_{d}\right)$ viscosity [21].

In the case of density, data were fitted to polynomial models of second degree simultaneously for concentration of solids and temperature.

\section{Results and discussion}

\subsection{Chemical characterization}

The chemical composition of peanut shell is displayed in Table 2. The obtained composition of dry matter resembles to other studied lignocellulosic materials, as almonds shells, sugarcane bagasse and rice straw [22], and even for some results presented by Castro \& Pereira-Jr. [4] for peanut shells. Total sugars indicate the maximum potential of conversion from lignocellulose compounds such as cellulose and hemicellulose.

\subsection{Zeta potential}

Zeta potential or surface charge of materials is strongly influenced by $\mathrm{pH}$, since it determines the degree of protonation of functional groups in the material surface [23]. Fig. 1 shows zeta potential of peanut shells as a function of $\mathrm{pH}$.

Among the $\mathrm{pH}$ values evaluated, increasing $\mathrm{pH}$ from 3 to 6 resulted in a significant deviation on zeta-potential value, with smaller influence between pH 6 and 7. If zeta potential values are near to zero, it is expected more interactions between particles, since there are no electrostatic repulsion between them. Similar behavior was also observed for suspensions of cellulose fibers of banana waste [24]. The addition of cationic compounds, such as $\mathrm{H}^{+}$, on negatively charged products may cause aggregation in different ways. The main mechanism is the charge screening, which reduces the zeta potential magnitude and the electrostatic repulsion between molecules, such as cellulose [25].

\subsection{Particles size distribution}

Volume particles size distribution showed a high polydispersity (span 1.886), probably due to the great amount of small size (between 3 and $12 \mu \mathrm{m}$ ) particles and some particles with larger sizes. Results showed that $10 \%$ of particles $\left(D_{1,0}\right)$ are smaller than $105.62 \mu \mathrm{m}$ while $10 \%$ of particles show larger sizes than $948.03 \mu \mathrm{m}\left(D_{9,0}\right)$, reflecting the high polydispersity even though a monomodal particle size distribution of powdered peanut shell (PPS) was observed by volume and number distribution (Fig. 2).

A significant difference between the peaks from Fig. 2a and b can be observed. Such difference is attributed to the fact that the larger particles represent a higher volume fraction, while smaller particles $(\sim 5 \mu \mathrm{m})$ represent the higher number fraction, once a great amount of small particles is necessary to occupy the same volume as a single big particle.

The mean volume weighted diameter $\left(D_{4,3}\right)$ was $492.68 \mu \mathrm{m}$, while the surface weighted diameter $\left(D_{3,2}\right)$ was $178.46 \mu \mathrm{m}$. In the presence of high content of fine particles, $D_{3,2}$ would give lower values than $D_{4,3}$, as observed for soybean extract [26] and the PPS evaluated in the present work. As $D_{3,2}$ is defined as the diameter of a sphere with the same volume/surface ratio [27], fine particles seem to have volume lower than the representative sphere when compared to its surface. Since this analysis consists to verify the light scattering pattern of a specific particle's volume, it is useful to compare the fraction of each size particles range present in the powder. Results indicated that most of the particles showed a diameter of around $6 \mu \mathrm{m}$ (mode).

\subsection{Optical microcopy (OM)}

Particles were observed through images obtained by optical microscopy (Fig. 3), showing particles with unlike size (high polydispersity)

Table 2

Chemical composition of peanut shells.

\begin{tabular}{|c|c|}
\hline Chemical composition & Results $^{\mathrm{c}}$ \\
\hline Moisture $\left(\mathrm{w} \cdot \mathrm{w}^{-1}, \mathrm{w} . \mathrm{b}.\right)$ & $11.0 \pm 0.1$ \\
\hline Dry matter $\left(\mathrm{w} \cdot \mathrm{w}^{-1}, \mathrm{w} . \mathrm{b}.\right)$ & $89.0 \pm 0.1$ \\
\hline Cellulose $^{\mathrm{a}}\left(\mathrm{w} \cdot \mathrm{w}^{-1}\right.$, d.b. $)$ & $37.1 \pm 1.0$ \\
\hline Hemicellulose $^{a}\left(w \cdot w^{-1}\right.$, d.b. $)$ & $33.4 \pm 0.6$ \\
\hline $\operatorname{Lignin}^{\mathrm{a}}\left(\mathrm{w} \cdot \mathrm{w}^{-1}\right.$, d.b. $)$ & $15.0 \pm 0.3$ \\
\hline Total sugars $^{\mathrm{b}}\left(\mathrm{g} \cdot \mathrm{L}^{-1}\right)$ & $65.1 \pm 1.6$ \\
\hline
\end{tabular}




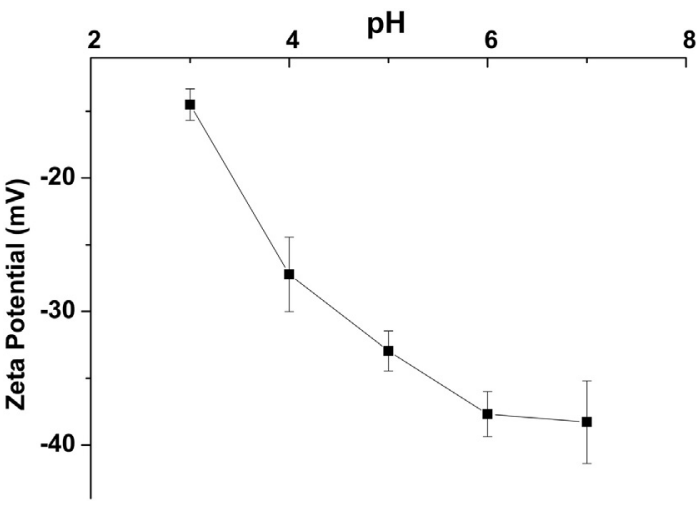

Fig. 1.Zeta potential of suspensions of powdered peanut shell (PPS) at different pH values.

and irregular shape. The morphology was typical of cellulosic material and their average aspect ratio $\left(a_{r}\right)$ was $1.86 \pm 0.72$.

\subsection{Flow behavior}

Fitting values of the 3-parameter non-linear regression, HerschelBulkley equation, are presented in Table 3. Fitting parameters show the rheological behavior as function of concentration, $\mathrm{pH}$ and temperature.

The rheological characteristics were very well-fitted to HerschelBulkley equation, with $\mathrm{R}^{2}>0.999$. Suspensions with solids concentration up to $8 \%$ showed flow behavior index close to 1 and $\tau_{0}$ close to zero, indicating Newtonian behavior as the dispersant solutions ( $0 \%$ of solids). Since flow behavior index is very close to the unit and there is no residual stress $\left(\tau_{0} \approx 0\right)$ for almost all cases, it brings the HerschelBulkley into Newton's equation. Probably, up to $8 \%$ of PPS the particles do not show significant interactions between them to induce a change in rheological behavior, predominating the dispersant properties.

The more concentrated suspensions $(>10 \% \mathrm{w} / \mathrm{w})$ showed pseudoplasticity (minimum $n$ value of 0.85 ) and a considerable increase in initial yield stress (up to $3.54 \mathrm{~Pa}$ ), which was also evidenced for slurries by Chen et al. [28] and Lin et al. [29]. Considering that yield stress represents the necessary initial energy to induce the flow, at higher solids concentration, the particles are more misaligned and disorganized, increasing $\tau_{0}$ values. Although the mechanism is unknown, authors suggested that in highly concentrated suspensions, the breakdown of a three dimensional network structure along the increase of shear rate promotes the release of interstitial water reducing on the apparent viscosity, which results in shear thinning behavior [30,31]. This effect was also verified in the different kind of suspensions such as some fruit pulps as tomato [32] and mango [33], slurries of limestone [34], nickel [35] and biomass of corn stover [36]. All of them were also characterized as shear thinning fluids with yield stress.

\subsection{Influence of $\mathrm{pH}$ on rheological parameters}

In addition to the particle's physical characteristics, affinity with the dispersant medium and the medium properties can hardly change the suspensions rheology [37]. This effect could be evaluated from zeta potential values, since a more pronounced particles aggregation are likely to occur at $\mathrm{pH}$ in which neutral surface charge is observed. Thus, in order to verify the $\mathrm{pH}$ influence on rheological parameters, a Tukey test at $95 \%$ confidence interval was used between the samples with 2 and $12 \%$ of solids at different $\mathrm{pH}$ values. Means and standard deviation can be seen in Table 4 .

Even though zeta potential indicated a tendency to agglomeration at more acidic $\mathrm{pH}$ values, rheological parameters did not show differences at varying $\mathrm{pH}$, confirming that $\mathrm{pH}$ solution did not affect the suspensions rheology. The absence of significant differences could be attributed to the hydrodynamic forces, which seems to be more pronounced than Brownian motion in systems with average particle size or aggregates higher than $100 \mu \mathrm{m}$ [38], which corresponded to the major fraction of the particles (Fig. 2a), and of electrostatic interactions, that would be favored by the acidic $\mathrm{pH}$.

\subsection{Solids concentration and temperature dependence}

Since $\mathrm{pH}$ did not show the affect the rheological parameters, solids concentration and temperature dependence on rheological parameters was evaluated at an average $\mathrm{pH}$ value (5.0). Apparent viscosity at a shear rate indicated for mixture process $\left(10 s^{-1}\right)$ [11] was analyzed and showed a similar effect described by Mewis \& Macosco [39] (Fig. 4), where an increase on suspensions' viscosity was observed as the solids concentration increased. Similar tendency was verified in other studies involving cellulosic fiber as dispersed material [36,40, 41]. An exponential model (Eq. 8) was used to fit the apparent viscosity data at $10 \mathrm{~s}^{-1}$ and resulted in Eq. (10).

$$
\begin{aligned}
\eta_{a p p ; 10 s^{-1}}(P a \cdot s)= & -0.0635+5.66 \\
& \times 10^{-5} \exp \left(\frac{17346.89}{R(T+273.15)}\right) X_{S}^{1.51}\left(R^{2}=0.928\right) .
\end{aligned}
$$

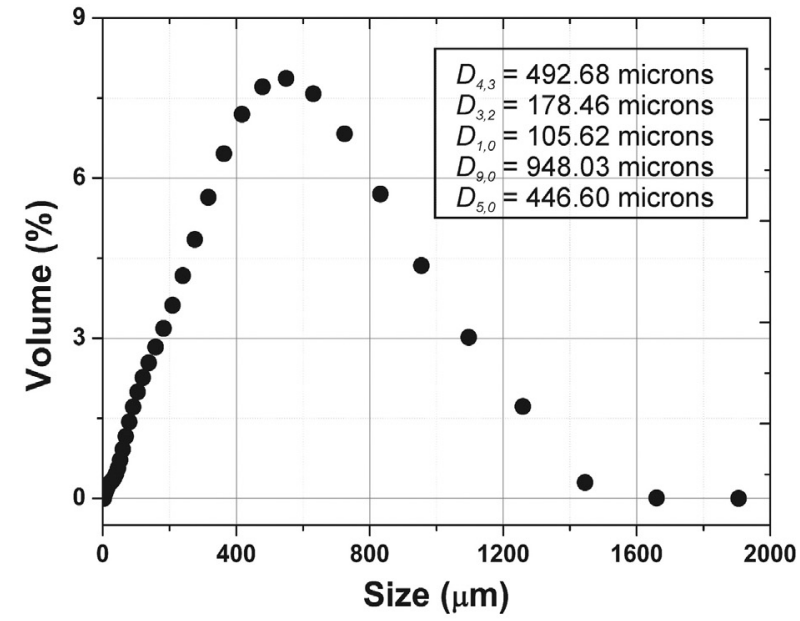

(a)

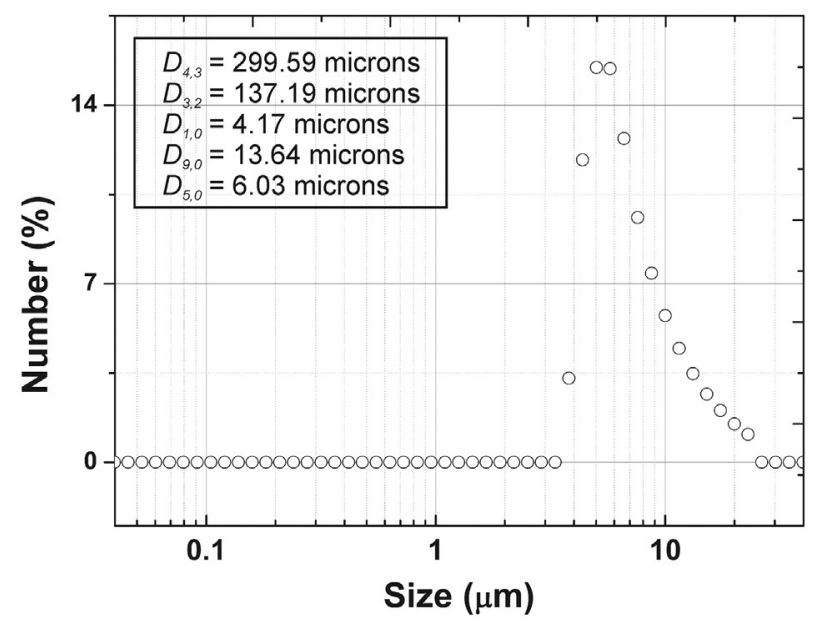

(b)

Fig. 2. Particles size distribution based on (a) volume and (b) number of particles. 

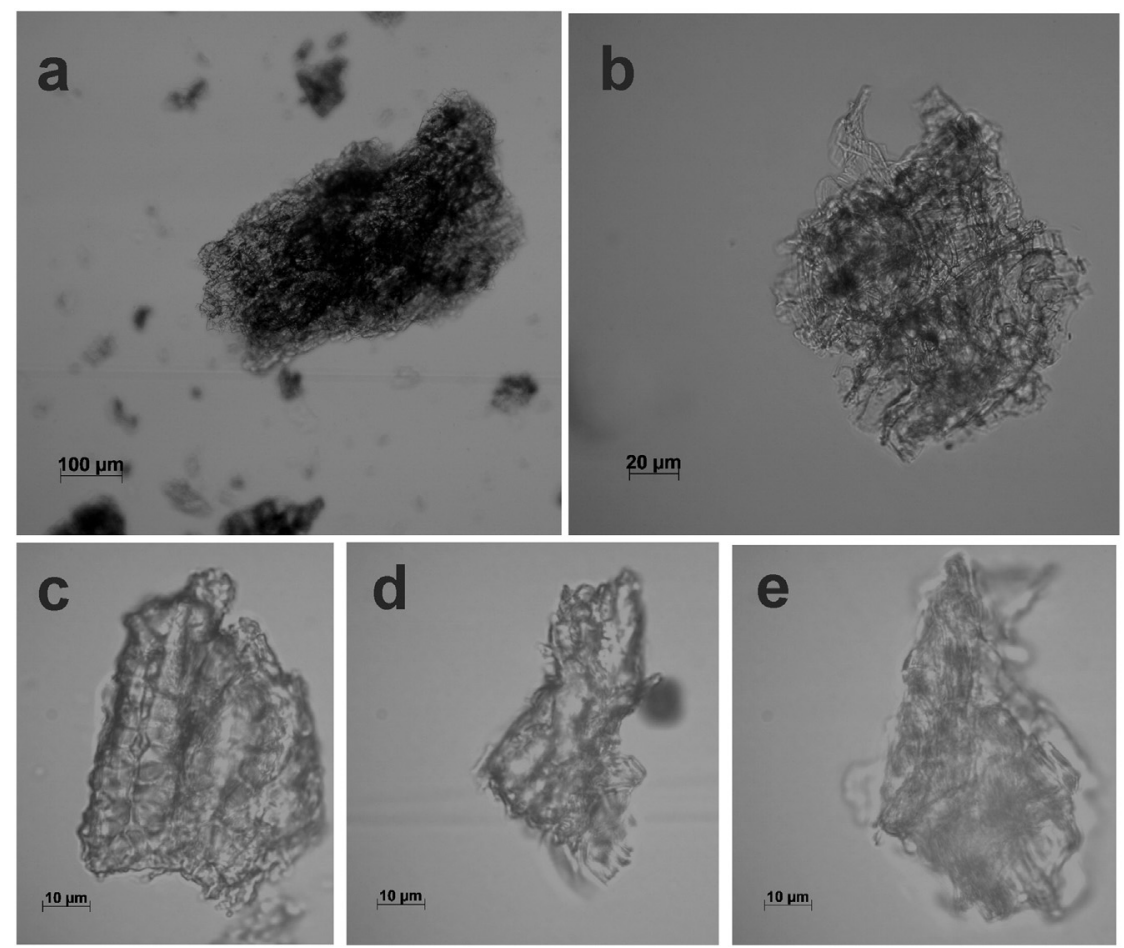

Fig. 3. Optical microscopy of PPS at different magnifications: a) $10 \times$; b) $40 \times$ and c, d and e) $100 \times$.

By analysis of variance (ANOVA) at 95\% of confidence using STATISTICA 10 (StatSoft, Tulsa, USA), apparent viscosity revealed a quadratic dependence on temperature and linear dependence on solid content (all with $p_{\text {value }}<0.05$ ).
All Herschel-Bulkley parameters were plotted as function of solids concentration and temperature (Fig. 5), allowing to fit separated models for initial yield stress (Eq. (11)), consistency coefficient (Eq. (12)) and flow behavior index (Eq. (13)), for later use in processes design calculation.

Table 3

Fitting parameters of Herschel-Bulkley equation for some suspensions.

\begin{tabular}{|c|c|c|c|c|c|c|c|c|c|c|}
\hline & & \multicolumn{9}{|c|}{ [Biomass] $(w / w)$} \\
\hline & & \multicolumn{3}{|l|}{$2 \%$} & \multicolumn{3}{|l|}{$8 \%$} & \multicolumn{3}{|l|}{$10 \%$} \\
\hline & & $\mathrm{pH} 3.0$ & pH 5.0 & pH 7.0 & pH 3.0 & pH 5.0 & $\mathrm{pH} 7.0$ & $\mathrm{pH} 3.0$ & pH 5.0 & $\mathrm{pH} 7.0$ \\
\hline \multirow[t]{4}{*}{$1{ }^{\circ} \mathrm{C}$} & $\tau_{0}$ & 0.0828 & 0.0897 & 0.0733 & 0.6337 & 1.3648 & 0.9521 & 3.0209 & 3.5440 & 3.0109 \\
\hline & $k$ & 0.2558 & 0.2545 & 0.2558 & 3.2755 & 3.6082 & 2.9116 & 5.7265 & 5.6382 & 5.7338 \\
\hline & $n$ & 1.0001 & 1.0009 & 0.9984 & 0.9955 & 1.0016 & 1.0013 & 0.8592 & 0.8604 & 0.8588 \\
\hline & $R^{2}$ & 0.9999 & 0.9999 & 0.9999 & 0.9999 & 0.9999 & 0.9999 & 0.9999 & 0.9999 & 0.9999 \\
\hline \multirow[t]{4}{*}{$10{ }^{\circ} \mathrm{C}$} & $\tau_{0}$ & 0.0595 & 0.0609 & 0.0650 & 0.7380 & 0.9791 & 0.7259 & 1.7602 & 1.6998 & 1.7137 \\
\hline & $k$ & 0.1599 & 0.1589 & 0.1580 & 1.9965 & 1.8379 & 1.9095 & 4.0616 & 4.0592 & 4.0831 \\
\hline & $n$ & 1.0002 & 1.0001 & 1.0009 & 1.0010 & 1.0026 & 0.9955 & 0.8727 & 0.8731 & 0.8711 \\
\hline & $R^{2}$ & 0.9999 & 0.9999 & 0.9999 & 0.9999 & 0.9999 & 0.9999 & 0.9999 & 0.9999 & 0.9999 \\
\hline \multirow[t]{4}{*}{$20{ }^{\circ} \mathrm{C}$} & $\tau_{0}$ & 0.0421 & 0.0468 & 0.0440 & 0.5833 & 0.5478 & 0.4848 & 1.5289 & 1.5200 & 1.5178 \\
\hline & $k$ & 0.1189 & 0.1177 & 0.1169 & 1.4708 & 1.4435 & 1.3423 & 2.7265 & 2.7384 & 2.7288 \\
\hline & $n$ & 0.9984 & 1.0006 & 1.0004 & 1.0013 & 1.0010 & 1.0007 & 0.8725 & 0.8712 & 0.8723 \\
\hline & $R^{2}$ & 0.9999 & 0.9999 & 0.9999 & 0.9999 & 0.9999 & 0.9999 & 0.9999 & 0.9999 & 0.9999 \\
\hline \multirow[t]{4}{*}{$30^{\circ} \mathrm{C}$} & $\tau_{0}$ & 0.0354 & 0.0364 & 0.0370 & 0.5102 & 0.4762 & 0.4113 & 0.9516 & 1.0097 & 0.9853 \\
\hline & $k$ & 0.0959 & 0.0959 & 0.0959 & 1.1490 & 1.1753 & 1.1241 & 2.4821 & 2.4921 & 2.4973 \\
\hline & $n$ & 1.0003 & 1.0002 & 1.0001 & 1.0003 & 1.0013 & 1.0010 & 0.8742 & 0.8737 & 0.8730 \\
\hline & $R^{2}$ & 0.9999 & 0.9999 & 0.9999 & 0.9999 & 0.9999 & 0.9999 & 0.9999 & 0.9999 & 0.9999 \\
\hline \multirow[t]{4}{*}{$40{ }^{\circ} \mathrm{C}$} & $\tau_{0}$ & 0.0322 & 0.0272 & 0.0302 & 0.3756 & 0.3754 & 0.4144 & 0.8723 & 0.9067 & 0.7682 \\
\hline & $k$ & 0.0825 & 0.0836 & 0.0818 & 1.0279 & 0.9997 & 0.9485 & 2.0392 & 2.0502 & 2.1015 \\
\hline & $n$ & 1.0009 & 0.9984 & 1.0005 & 1.0013 & 1.0013 & 1.0026 & 0.8685 & 0.8675 & 0.8620 \\
\hline & $R^{2}$ & 0.9999 & 0.9999 & 0.9999 & 0.9999 & 0.9999 & 0.9999 & 0.9999 & 0.9999 & 0.9999 \\
\hline \multirow[t]{4}{*}{$50{ }^{\circ} \mathrm{C}$} & $\tau_{0}$ & 0.0249 & 0.0267 & 0.0223 & 0.2096 & 0.3502 & 0.3121 & 0.5401 & 0.5239 & 0.4200 \\
\hline & $k$ & 0.0749 & 0.0736 & 0.0745 & 0.9670 & 0.8975 & 0.8484 & 2.0618 & 2.0548 & 2.1169 \\
\hline & $n$ & 1.0001 & 1.0008 & 0.9985 & 0.9955 & 1.0016 & 1.0013 & 0.8704 & 0.8705 & 0.8640 \\
\hline & $R^{2}$ & 0.9999 & 0.9999 & 0.9999 & 0.9999 & 0.9999 & 0.9999 & 0.9999 & 0.9999 & 0.9999 \\
\hline \multirow[t]{4}{*}{$60{ }^{\circ} \mathrm{C}$} & $\tau_{0}$ & 0.0218 & 0.0236 & 0.0194 & 0.3398 & 0.2371 & 0.2978 & 0.5018 & 0.6648 & 0.4759 \\
\hline & $k$ & 0.0689 & 0.0686 & 0.0695 & 0.8413 & 0.8819 & 0.8232 & 1.9071 & 1.8663 & 1.8927 \\
\hline & $n$ & 1.0001 & 1.0009 & 0.9984 & 1.0026 & 0.9955 & 1.0016 & 0.8667 & 0.8700 & 0.8686 \\
\hline & $R^{2}$ & 0.9999 & 0.9999 & 0.9999 & 0.9999 & 0.9999 & 0.9999 & 0.9999 & 0.9999 & 0.9999 \\
\hline
\end{tabular}


Table 4

Means and standard deviation of Herschel-Bulkley parameters for the runs in triplicate at 2 and $12 \%$ of solids.

\begin{tabular}{|c|c|c|c|c|c|c|c|}
\hline Biomass $(\% w / w)$ & Rheological parameters & $T\left({ }^{\circ} \mathrm{C}\right)$ & $\mathrm{pH}=3$ & $\mathrm{pH}=4$ & $\mathrm{pH}=5$ & $\mathrm{pH}=6$ & $\mathrm{pH}=7$ \\
\hline \multirow{19}{*}{2} & \multirow{7}{*}{$\tau_{0}(\mathrm{mPa})$} & 1 & $76.80 \pm 11.06^{a}$ & $85.16 \pm 30.72^{a}$ & $84.28 \pm 4.91^{a}$ & $89.50 \pm 16.73^{a}$ & $76.06 \pm 5.48^{a}$ \\
\hline & & 10 & $67.88 \pm 9.23^{a}$ & $56.79 \pm 6.91^{\mathrm{a}}$ & $63.07 \pm 2.75^{a}$ & $62.58 \pm 3.07^{\mathrm{a}}$ & $62.11 \pm 2.62^{a}$ \\
\hline & & 20 & $45.84 \pm 4.17^{\mathrm{a}}$ & $44.01 \pm 6.18^{a}$ & $46.76 \pm 0.46^{a}$ & $45.51 \pm 1.68^{a}$ & $45.96 \pm 2.11^{\mathrm{a}}$ \\
\hline & & 30 & $37.43 \pm 2.08^{a}$ & $39.48 \pm 9.14^{\mathrm{a}}$ & $36.58 \pm 2.82^{a}$ & $36.22 \pm 1.92^{\mathrm{a}}$ & $37.87 \pm 1.28^{a}$ \\
\hline & & 40 & $30.92 \pm 1.22^{\mathrm{a}}$ & $33.23 \pm 7.36^{\mathrm{a}}$ & $31.10 \pm 3.53^{a}$ & $28.83 \pm 7.70^{\mathrm{a}}$ & $30.03 \pm 2.80^{a}$ \\
\hline & & 50 & $21.67 \pm 3.60^{\mathrm{a}}$ & $27.25 \pm 4.57^{\mathrm{a}}$ & $29.71 \pm 6.45^{\mathrm{a}}$ & $24.96 \pm 3.68^{a}$ & $23.52 \pm 1.73^{\mathrm{a}}$ \\
\hline & & 60 & $22.74 \pm 2.13^{a}$ & $24.57 \pm 5.38^{a}$ & $22.42 \pm 1.16^{\mathrm{a}}$ & $22.48 \pm 2.39^{a}$ & $20.94 \pm 2.28^{a}$ \\
\hline & \multirow{7}{*}{$k\left(\mathrm{mPa} \cdot \mathrm{s}^{\mathrm{n}}\right)$} & 1 & $257.45 \pm 3.26^{\mathrm{a}}$ & $257.18 \pm 6.55^{a}$ & $255.29 \pm 0.72^{a}$ & $253.12 \pm 2.36^{\mathrm{a}}$ & $253.80 \pm 1.81^{\mathrm{a}}$ \\
\hline & & 10 & $158.61 \pm 1.41^{\mathrm{a}}$ & $160.72 \pm 2.24^{\mathrm{a}}$ & $158.40 \pm 0.50^{\mathrm{a}}$ & $158.38 \pm 0.39^{a}$ & $158.35 \pm 0.29^{a}$ \\
\hline & & 20 & $117.96 \pm 0.85^{a}$ & $118.56 \pm 1.71^{\mathrm{a}}$ & $117.74 \pm 0.14^{\mathrm{a}}$ & $116.75 \pm 0.12^{a}$ & $16.75 \pm 0.10^{a}$ \\
\hline & & 30 & $95.77 \pm 0.07^{\mathrm{a}}$ & $89.35 \pm 1.41^{b}$ & $95.69 \pm 0.26^{a}$ & $95.67 \pm 0.18^{a}$ & $95.81 \pm 0.10^{a}$ \\
\hline & & 40 & $82.58 \pm 0.10^{a}$ & $82.29 \pm 1.09^{a}$ & $82.90 \pm 0.60^{a}$ & $83.50 \pm 1.93^{a}$ & $82.03 \pm 0.48^{a}$ \\
\hline & & 50 & $75.51 \pm 1.34^{\mathrm{a}}$ & $73.47 \pm 0.69^{\mathrm{a}, \mathrm{b}}$ & $73.11 \pm 0.98^{b}$ & $73.71 \pm 0.18^{\mathrm{a}, \mathrm{b}}$ & $73.98 \pm 0.46^{\mathrm{a}, \mathrm{b}}$ \\
\hline & & 60 & $68.74 \pm 0.33^{a}$ & $68.41 \pm 0.79^{\mathrm{a}}$ & $68.79 \pm 0.19^{a}$ & $68.84 \pm 0.14^{\mathrm{a}}$ & $68.92 \pm 0.49^{\mathrm{a}}$ \\
\hline & \multirow{7}{*}{$n(-)$} & 1 & $1.00 \pm 0.00^{\mathrm{a}}$ & $1.00 \pm 0.00^{\mathrm{a}}$ & $1.00 \pm 0.00^{\mathrm{a}}$ & $1.00 \pm 0.00^{\mathrm{a}}$ & $1.00 \pm 0.00^{\mathrm{a}}$ \\
\hline & & 10 & $1.00 \pm 0.00^{\mathrm{a}}$ & $1.00 \pm 0.00^{\mathrm{a}}$ & $1.00 \pm 0.00^{\mathrm{a}}$ & $1.00 \pm 0.00^{\mathrm{a}}$ & $1.00 \pm 0.00^{\mathrm{a}}$ \\
\hline & & 20 & $1.00 \pm 0.00^{\mathrm{a}}$ & $1.00 \pm 0.00^{a}$ & $1.00 \pm 0.00^{\mathrm{a}}$ & $1.00 \pm 0.00^{\mathrm{a}}$ & $1.00 \pm 0.00^{\mathrm{a}}$ \\
\hline & & 30 & $1.00 \pm 0.00^{\mathrm{a}}$ & $1.00 \pm 0.00^{\mathrm{a}}$ & $1.00 \pm 0.00^{\mathrm{a}}$ & $1.00 \pm 0.00^{\mathrm{a}}$ & $1.00 \pm 0.00^{\mathrm{a}}$ \\
\hline & & 40 & $1.00 \pm 0.00^{\mathrm{a}}$ & $1.00 \pm 0.00^{\mathrm{a}}$ & $1.00 \pm 0.00^{\mathrm{a}}$ & $1.00 \pm 0.01^{\mathrm{a}}$ & $1.00 \pm 0.00^{\mathrm{a}}$ \\
\hline \multirow{23}{*}{12} & & 50 & $1.00 \pm 0.00^{a}$ & $1.00 \pm 0.00^{\mathrm{a}}$ & $1.00 \pm 0.00^{a}$ & $1.00 \pm 0.00^{a}$ & $1.00 \pm 0.00^{a}$ \\
\hline & & 60 & $1.00 \pm 0.00^{\mathrm{a}}$ & $1.00 \pm 0.00^{\mathrm{a}}$ & $1.00 \pm 0.00^{\mathrm{a}}$ & $1.00 \pm 0.00^{\mathrm{a}}$ & $1.00 \pm 0.00^{a}$ \\
\hline & \multirow{8}{*}{$\tau_{0}(\mathrm{mPa})$} & 1 & $3125.47 \pm 72.12^{a}$ & $3140.77 \pm 61.47^{\mathrm{a}}$ & $2895.23 \pm 582.46^{a}$ & $2931.76 \pm 598.53^{a}$ & $3026.46 \pm 208.40^{a}$ \\
\hline & & 10 & $1774.67 \pm 63.65^{\mathrm{a}}$ & $1861.19 \pm 175.73^{a}$ & $1914.41 \pm 166.73^{a}$ & $1540.47 \pm 364.99^{a}$ & $1691.52 \pm 149.52^{a}$ \\
\hline & & 20 & $1619.21 \pm 124.14^{\mathrm{a}}$ & $1558.56 \pm 13.01^{\mathrm{a}}$ & $1543.96 \pm 265.46^{a}$ & $1662.27 \pm 112.85^{a}$ & $1505.55 \pm 93.55^{a}$ \\
\hline & & 30 & $1032.31 \pm 60.71^{\mathrm{a}}$ & $1050.41 \pm 26.48^{a}$ & $938.79 \pm 298.07^{a}$ & $936.88 \pm 297.43^{a}$ & $1012.85 \pm 145.41^{a}$ \\
\hline & & 40 & $937.44 \pm 50.93$ & $910.38 \pm 3.40^{\mathrm{a}}$ & $972.08 \pm 55.16^{a}$ & $885.68 \pm 251.72^{a}$ & $881.98 \pm 71.66^{\mathrm{a}}$ \\
\hline & & 50 & $563.94 \pm 31.89^{a}$ & $575.04 \pm 52.07^{a}$ & $467.42 \pm 204.92^{a}$ & $648.81 \pm 94.53^{a}$ & $597.57 \pm 45.48^{a}$ \\
\hline & & 60 & $543.12 \pm 82.48^{a}$ & $494.10 \pm 3.98^{\mathrm{a}}$ & $523.05 \pm 51.16^{a}$ & $531.52 \pm 29.46^{a}$ & $565.02 \pm 66.33^{a}$ \\
\hline & & 1 & $5941.65 \pm 24.84^{a}$ & $5933.67 \pm 18.84^{a}$ & $6005.47 \pm 220.71^{a}$ & $6001.84 \pm 221.26^{a}$ & $5994.65 \pm 77.66^{a}$ \\
\hline & \multirow{6}{*}{$k\left(\mathrm{mPa} \cdot \mathrm{s}^{\mathrm{n}}\right)$} & 10 & $4242.28 \pm 16.36^{\mathrm{a}}$ & $4225.14 \pm 36.09^{a}$ & $4194.92 \pm 25.85^{\mathrm{a}}$ & $4315.14 \pm 132.74^{a}$ & $4271.24 \pm 62.60^{a}$ \\
\hline & & 20 & $2838.21 \pm 27.71^{\mathrm{a}}$ & $2848.99 \pm 8.86^{\mathrm{a}}$ & $2860.49 \pm 80.65^{a}$ & $2812.53 \pm 17.39^{a}$ & $2867.97 \pm 39.40^{a}$ \\
\hline & & 30 & $2597.80 \pm 23.77^{a}$ & $2595.05 \pm 11.97^{\mathrm{a}}$ & $2636.20 \pm 92.68^{a}$ & $2640.54 \pm 90.34^{\mathrm{a}}$ & $2616.05 \pm 42.55^{a}$ \\
\hline & & 40 & $2132.17 \pm 17.72^{a}$ & $2140.70 \pm 9.64^{\mathrm{a}}$ & $2127.84 \pm 16.35^{a}$ & $2158.40 \pm 81.80^{a}$ & $2142.58 \pm 45.50^{a}$ \\
\hline & & 50 & $2157.88 \pm 3.79^{a}$ & $2134.98 \pm 23.35^{a}$ & $2184.27 \pm 74.62^{a}$ & $2130.89 \pm 18.51^{\mathrm{a}}$ & $2144.49 \pm 2.11^{\mathrm{a}}$ \\
\hline & & 60 & $1957.22 \pm 16.42^{\mathrm{a}}$ & $1968.02 \pm 8.67^{\mathrm{a}}$ & $1955.21 \pm 18.46^{a}$ & $1956.85 \pm 14.43^{a}$ & $1950.18 \pm 12.57^{a}$ \\
\hline & \multirow{7}{*}{$n(-)$} & 1 & $0.86 \pm 0.00^{a}$ & $0.86 \pm 0.00^{a}$ & $0.86 \pm 0.01^{\mathrm{a}}$ & $0.86 \pm 0.01^{\mathrm{a}}$ & $0.86 \pm 0.00^{a}$ \\
\hline & & 10 & $0.87 \pm 0.00^{\mathrm{a}}$ & $0.87 \pm 0.00^{\mathrm{a}}$ & $0.87 \pm 0.00^{a}$ & $0.87 \pm 0.01^{a}$ & $0.87 \pm 0.00^{\mathrm{a}}$ \\
\hline & & 20 & $0.87 \pm 0.00^{\mathrm{a}}$ & $0.87 \pm 0.00^{\mathrm{a}}$ & $0.87 \pm 0.01^{\mathrm{a}}$ & $0.87 \pm 0.00^{\mathrm{a}}$ & $0.87 \pm 0.00^{\mathrm{a}}$ \\
\hline & & 30 & $0.87 \pm 0.00^{a}$ & $0.87 \pm 0.00^{\mathrm{a}}$ & $0.87 \pm 0.01^{\mathrm{a}}$ & $0.87 \pm 0.01^{a}$ & $0.87 \pm 0.00^{a}$ \\
\hline & & 40 & $0.87 \pm 0.00^{a}$ & $0.87 \pm 0.00^{\mathrm{a}}$ & $0.87 \pm 0.00^{a}$ & $0.87 \pm 0.01^{\mathrm{a}}$ & $0.87 \pm 0.00^{\mathrm{a}}$ \\
\hline & & 50 & $0.87 \pm 0.00^{\mathrm{a}}$ & $0.87 \pm 0.00^{\mathrm{a}}$ & $0.87 \pm 0.01^{\mathrm{a}}$ & $0.87 \pm 0.00^{\mathrm{a}}$ & $0.87 \pm 0.00^{\mathrm{a}}$ \\
\hline & & 60 & $0.87 \pm 0.00^{a}$ & $0.87 \pm 0.00^{\mathrm{a}}$ & $0.87 \pm 0.00^{a}$ & $0.87 \pm 0.00^{\mathrm{a}}$ & $0.87 \pm 0.00^{\mathrm{a}}$ \\
\hline
\end{tabular}

a,b Letters in the same line represent no significant difference at 95\% of confidence interval by Tukey test.

The following fitted models with the respective $R^{2}$ are:

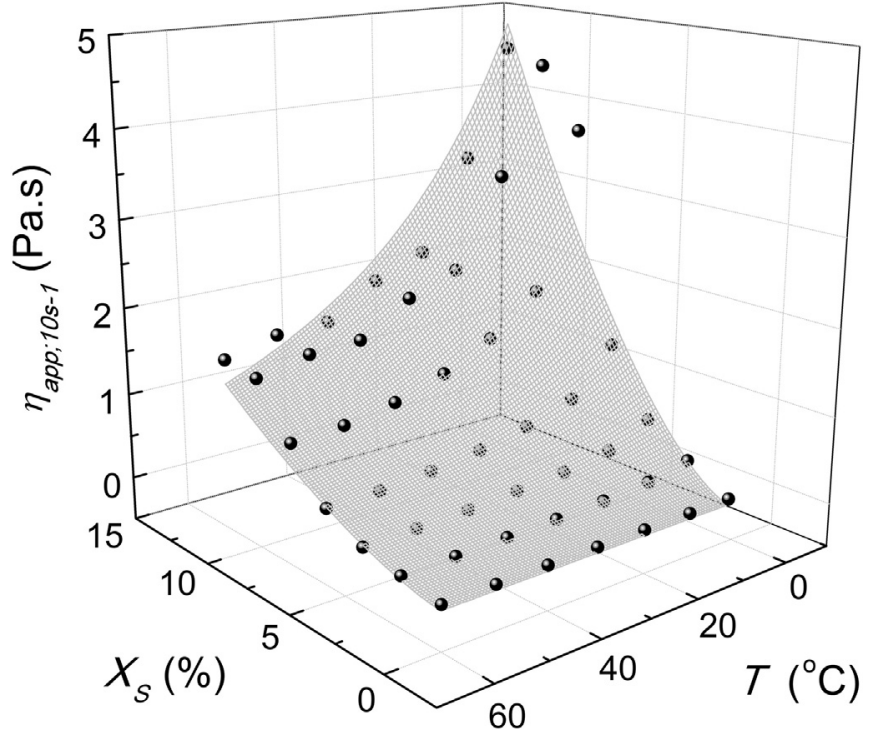

$\tau_{0}(P a)=-0.016+2.56 \times 10^{-7} \exp \left(\frac{25126.29}{R(T+273.15)}\right) X_{S}^{2.18}\left(R^{2}=0.895\right)$

$k\left(P a \cdot s^{n}\right)=-0.063+3.81 \times 10^{-5} \exp \left(\frac{17050.71}{R(T+273.15)}\right) X_{S}^{1.82}\left(R^{2}=0.930\right)$

$n($ dimensionless $)=\exp \left(0.01 X_{S}-0.002 X_{S}^{2}-\frac{8.76}{R(273.15)}\right)\left(R^{2}=0.820\right)$.

Consistency coefficient and yield stress have a second degree of dependence on temperature and solids content. Higher temperature favored molecular movement, reducing the viscosity, consistency index and the yield stress. However, the suspension solids increase leads to spatial structures formation, hindering the motion and increasing the resistance to the flow [42]. The effect of temperature on flow behavior index was not evident as reported by other authors for biomass [43] and petrochemical [44] slurries. On the other hand, the solid concentration is responsible by interfering quadratically on flow behavior index, inducing shear thinning, probably due to particle-particle interactions.
Fig. 4. Apparent viscosity (at $10 \mathrm{~s}^{-1}$ ) as function of solids content (\%) and temperature $\left({ }^{\circ} \mathrm{C}\right)$. 
a)

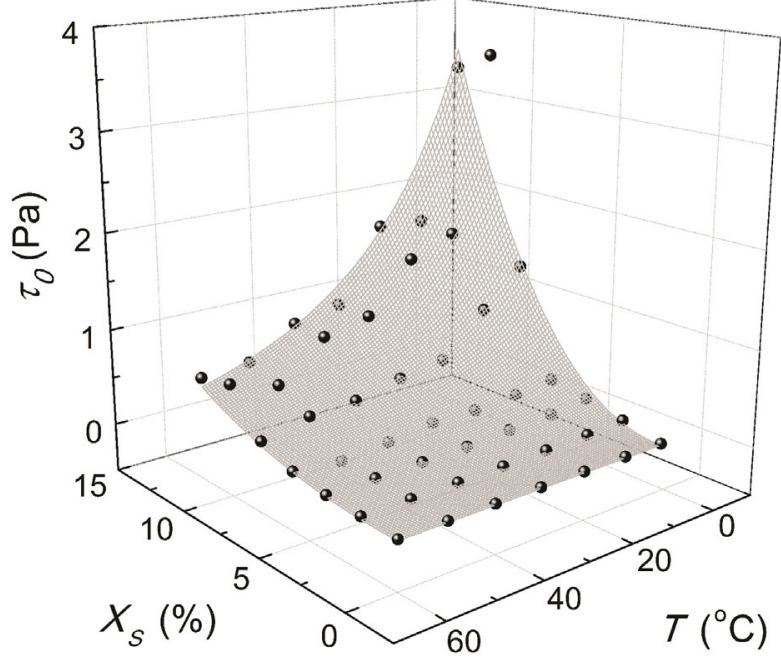

b)

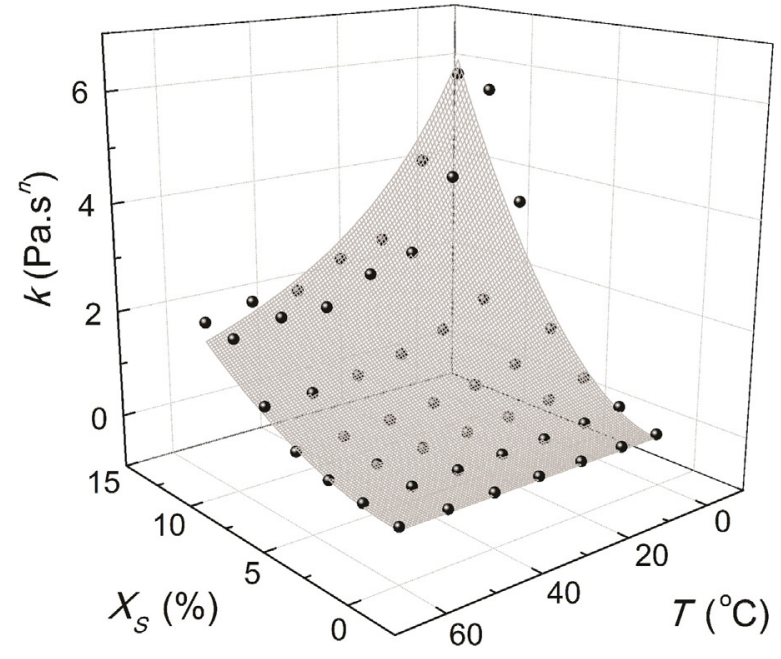

C)

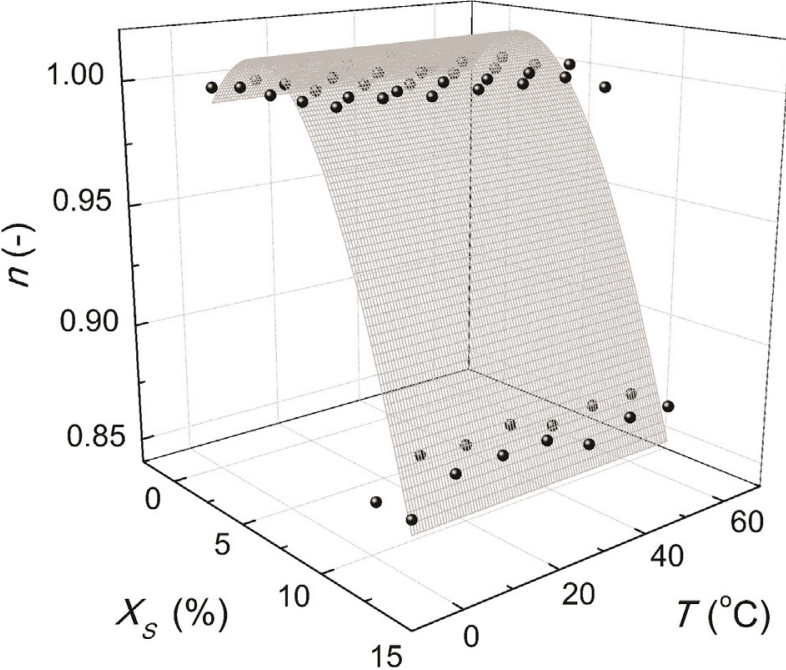

Fig. 5. Initial yield stress (a), consistency coefficient (b) and flow behavior index (c) dependence on temperature $\left({ }^{\circ} \mathrm{C}\right)$ and solids content $(\%)$ at $\mathrm{pH} 5.0$.

Such strong solids effect was also observed by Qiu \& Rao [45] for apple purée suspension.

Evaluating the behavior of relative viscosity $\left(\eta_{S} / \eta_{d}\right)$ as function of solids concentration, up to $8 \%(w / w)$ of solids, an exponential tendency was observed. However, at higher solids content, a significant deviation on the slope was observed for all $\mathrm{pH}$ values. Data of others $\mathrm{pH}$ is not shown, since this behavior followed the same pattern as presented in Fig. 6 for $\mathrm{pH}$ 5.0.

Even though a pronounced increase of relative viscosity was expected at higher amount of particles, a decrease on the slope of the curve was observed for solids content between 8 and $12 \%(w / w)$. In these cases, the relative viscosity observed was hardly influenced by solids content like at lower concentrations. One theory capable to explain this deviation it is the effect described by Farris [46]. This author proposed that fine particles can act like dispersant when inserted in a suspension with larger particles, facilitating the flow of coarse particles. Even though fines were also observed at lower solids concentration, this behavior was pronounced only at higher concentrations, when there is an increase on the particle-particle interactions. The particles size distribution (in number of particles) reinforces this idea, once a large number of particles ( 86\%) showed size below $10 \mu \mathrm{m}$, while $10 \%$ showed size larger than $13.637 \mu \mathrm{m}$ (Fig. 2a). By Fig. 6, it can be concluded that Farris effect is pronounced when $10 \%$ of solids is reached. At this concentration $8.6 \mathrm{~g}$ of fines and $1.4 \mathrm{~g}$ of coarse are encountered in $100 \mathrm{~g}$ of suspension, establishing the beginning of Farris effect. The fines concentration reaches similar value as reported by Farris [46] when $10.7 \%$ of fines were added into the original suspension.

\subsection{Density evaluation}

As verified for rheology, the Tukey test showed no significant differences for densities at different $\mathrm{pH}$. Table 5 shows density values as function of solids concentration $(0-12 \% w / w)$ and temperature $\left(1-60{ }^{\circ} \mathrm{C}\right)$ at different $\mathrm{pH}$ values.

Density was negatively influenced by temperature, while a rise in solids content promoted an increase of density (Fig. 7). Temperature diminishes the interactive forces between molecules, dispersing them from each other. As the solid content gets higher, density approximated to values reported by Abdullah et al. [47] of $1250 \mathrm{~kg} / \mathrm{m}^{3}$ for biochar slurry at $20 \%(w / w)$ of solids.

ANOVA allowed asserting that both temperature and solids content influence quadratically the values of density, resulting in a second order polynomial model. The non-linear regression resulted in a $R^{2}=0.951$ :

$\rho\left(\mathrm{kg} / \mathrm{m}^{3}\right)=993.56+1.47 X_{S}+0.12 X_{S}^{2}+0.03 T-0.0038 T^{2}$.

A linear regression between the experimental versus predicted data presented an angular coefficient of 0.98 , very close to the unit, which represents a good accuracy of the model.

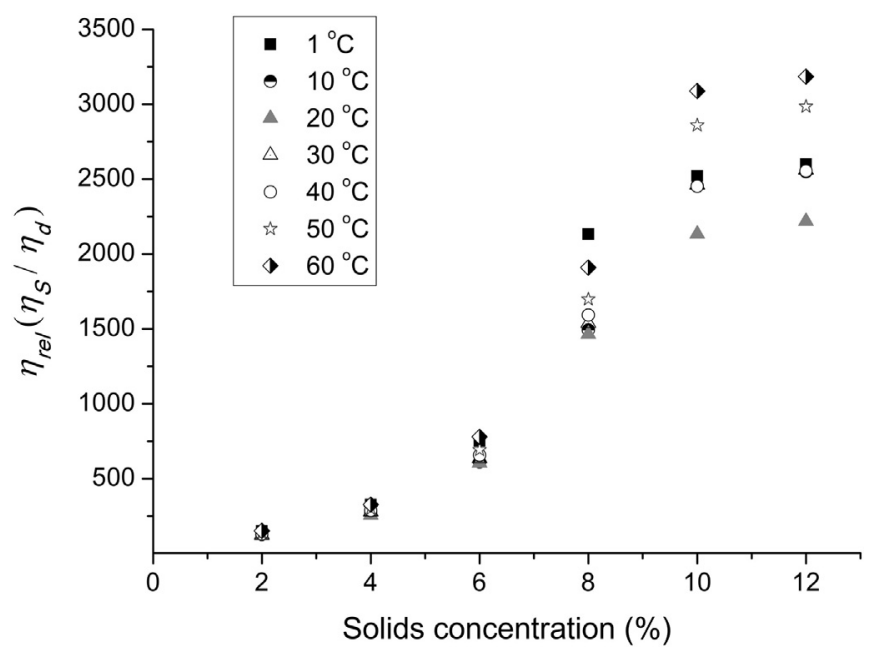

Fig. 6. Relative viscosity as function of PPS concentration at pH 5.0. 
Table 5

Density of acidic PPS suspensions at different temperature $\left({ }^{\circ} \mathrm{C}\right)$ and concentration of biomass (\%).

\begin{tabular}{|c|c|c|c|c|c|c|}
\hline \multirow[t]{2}{*}{ Biomass $(\% w / w)$} & \multirow[t]{2}{*}{$T\left({ }^{\circ} \mathrm{C}\right)$} & \multicolumn{5}{|c|}{ Density of peanut shells in acid solutions $\left(\mathrm{kg} / \mathrm{m}^{3}\right)$} \\
\hline & & $\mathrm{pH}=3$ & $\mathrm{pH}=4$ & $\mathrm{pH}=5$ & $\mathrm{pH}=6$ & $\mathrm{pH}=7$ \\
\hline \multirow{7}{*}{0} & 1 & $998.1 \pm 1.4^{\mathrm{a}}$ & $997.9 \pm 0.8^{\mathrm{a}}$ & $996.6 \pm 0.6^{\mathrm{a}}$ & $994.7 \pm 4.1^{\mathrm{a}}$ & $993.4 \pm 0.8^{\mathrm{a}}$ \\
\hline & 10 & $998.5 \pm 1.8^{\mathrm{a}}$ & $997.7 \pm 0.7^{\mathrm{a}}$ & $994.2 \pm 2.1^{\mathrm{a}}$ & $994.4 \pm 4.1^{\mathrm{a}}$ & $994.2 \pm 3.4^{\mathrm{a}}$ \\
\hline & 20 & $998.1 \pm 0.9^{\mathrm{a}}$ & $995.7 \pm 1.0^{\mathrm{a}, \mathrm{b}}$ & $995.5 \pm 1.2^{\mathrm{a}, \mathrm{b}}$ & $993.1 \pm 4.0^{\mathrm{a}, \mathrm{b}}$ & $991.9 \pm 0.8^{b}$ \\
\hline & 30 & $994.5 \pm 1.9^{\mathrm{a}}$ & $991.3 \pm 0.6^{\mathrm{a}}$ & $993.7 \pm 1.6^{\mathrm{a}}$ & $993.6 \pm 2.3^{a}$ & $991.6 \pm 0.2^{\mathrm{a}}$ \\
\hline & 40 & $993.6 \pm 0.9^{\mathrm{a}}$ & $990.6 \pm 0.6^{b}$ & $990.3 \pm 0.6^{b}$ & $989.0 \pm 0.2^{b, c}$ & $988.5 \pm 0.7^{c}$ \\
\hline & 50 & $991.1 \pm 0.6^{\mathrm{a}}$ & $987.0 \pm 1.7^{\mathrm{a}}$ & $987.1 \pm 1.6^{\mathrm{a}}$ & $985.3 \pm 4.0^{\mathrm{a}}$ & $986.8 \pm 3.1^{\mathrm{a}}$ \\
\hline & 60 & $986.0 \pm 1.0^{\mathrm{a}}$ & $982.9 \pm 3.4^{\mathrm{a}}$ & $984.7 \pm 0.7^{\mathrm{a}}$ & $983.0 \pm 0.9^{a}$ & $982.7 \pm 3.1^{\mathrm{a}}$ \\
\hline \multirow{7}{*}{2} & 1 & $990.5 \pm 3.7^{\mathrm{a}}$ & $995.4 \pm 7.7^{\mathrm{a}}$ & $995.4 \pm 3.4^{\mathrm{a}}$ & $990.8 \pm 8.7^{a}$ & $986.7 \pm 9.9^{a}$ \\
\hline & 10 & $992.2 \pm 8.1^{\mathrm{a}}$ & $994.0 \pm 1.8^{\mathrm{a}}$ & $995.0 \pm 6.3^{a}$ & $994.5 \pm 6.0^{\mathrm{a}}$ & $993.5 \pm 6.4^{\mathrm{a}}$ \\
\hline & 20 & $991.7 \pm 1.8^{\mathrm{a}}$ & $994.3 \pm 5.1^{\mathrm{a}}$ & $993.1 \pm 3.0^{\mathrm{a}}$ & $992.7 \pm 6.2^{\mathrm{a}}$ & $992.2 \pm 13.7^{a}$ \\
\hline & 30 & $997.6 \pm 4.1^{\mathrm{a}}$ & $999.6 \pm 7.2^{\mathrm{a}}$ & $987.5 \pm 2.9^{\mathrm{a}}$ & $991.7 \pm 2.9^{\mathrm{a}}$ & $986.9 \pm 7.1^{\mathrm{a}}$ \\
\hline & 40 & $982.4 \pm 1.9^{\mathrm{a}}$ & $988.8 \pm 4.6^{\mathrm{a}}$ & $988.9 \pm 4.1^{\mathrm{a}}$ & $987.9 \pm 8.2^{\mathrm{a}}$ & $989.4 \pm 12.1^{\mathrm{a}}$ \\
\hline & 50 & $984.9 \pm 5.1^{\mathrm{a}}$ & $986.3 \pm 4.1^{\mathrm{a}}$ & $984.4 \pm 3.9^{\mathrm{a}}$ & $977.2 \pm 6.3^{\mathrm{a}}$ & $986.1 \pm 4.5^{\mathrm{a}}$ \\
\hline & 60 & $975.3 \pm 4.3^{\mathrm{a}}$ & $981.1 \pm 4.3^{\mathrm{a}}$ & $979.7 \pm 3.9^{\mathrm{a}}$ & $977.0 \pm 3.9^{\mathrm{a}}$ & $981.3 \pm 4.6^{\mathrm{a}}$ \\
\hline \multirow{7}{*}{4} & 1 & $1000.2 \pm 3.7^{\mathrm{a}}$ & $1002.2 \pm 7.7^{\mathrm{a}}$ & $1003.0 \pm 3.4^{\mathrm{a}}$ & $994.0 \pm 8.8^{a}$ & $1001.5 \pm 10.1^{a}$ \\
\hline & 10 & $1002.7 \pm 8.1^{\mathrm{a}}$ & $1003.0 \pm 1.9^{\mathrm{a}}$ & $1001.8 \pm 6.3^{a}$ & $999.5 \pm 6.0^{\mathrm{a}}$ & $1000.8 \pm 6.4^{\mathrm{a}}$ \\
\hline & 20 & $1000.9 \pm 1.8^{a}$ & $1000.4 \pm 5.1^{\mathrm{a}}$ & $996.8 \pm 3.0^{\mathrm{a}}$ & $992.7 \pm 6.2^{\mathrm{a}}$ & $996.3 \pm 13.7^{a}$ \\
\hline & 30 & $994.7 \pm 4.1^{\mathrm{a}}$ & $998.6 \pm 7.2^{\mathrm{a}}$ & $999.1 \pm 2.9^{a}$ & $998.1 \pm 3.0^{\mathrm{a}}$ & $999.6 \pm 7.2^{\mathrm{a}}$ \\
\hline & 40 & $994.7 \pm 1.9^{\mathrm{a}}$ & $999.8 \pm 4.6^{\mathrm{a}}$ & $995.8 \pm 4.1^{\mathrm{a}}$ & $995.3 \pm 8.2^{\mathrm{a}}$ & $997.0 \pm 12.2^{a}$ \\
\hline & 50 & $992.7 \pm 5.1^{\mathrm{a}}$ & $985.5 \pm 4.1^{\mathrm{a}}$ & $993.4 \pm 4.0^{\mathrm{a}}$ & $988.5 \pm 6.4^{\mathrm{a}}$ & $989.7 \pm 4.5^{\mathrm{a}}$ \\
\hline & 60 & $987.1 \pm 4.3^{\mathrm{a}}$ & $989.7 \pm 4.4^{\mathrm{a}}$ & $989.6 \pm 3.9^{\mathrm{a}}$ & $989.6 \pm 4.0^{\mathrm{a}}$ & $993.3 \pm 4.6^{\mathrm{a}}$ \\
\hline \multirow{7}{*}{6} & 1 & $1011.9 \pm 3.7^{\mathrm{a}}$ & $1005.0 \pm 3.9^{\mathrm{a}}$ & $1009.1 \pm 0.7^{\mathrm{a}}$ & $1004.8 \pm 3.4^{\mathrm{a}}$ & $1006.0 \pm 3.8^{\mathrm{a}}$ \\
\hline & 10 & $1010.3 \pm 8.2^{\mathrm{a}}$ & $1009.0 \pm 7.6^{\mathrm{a}}$ & $1009.0 \pm 1.2^{\mathrm{a}}$ & $1000.4 \pm 12.6^{a}$ & $1006.5 \pm 1.6^{\mathrm{a}}$ \\
\hline & 20 & $1001.9 \pm 1.8^{\mathrm{a}}$ & $1007.5 \pm 2.6^{a}$ & $1007.3 \pm 5.7^{\mathrm{a}}$ & $999.3 \pm 7.8^{\mathrm{a}}$ & $1005.4 \pm 4.6^{\mathrm{a}}$ \\
\hline & 30 & $1007.9 \pm 4.1^{\mathrm{a}}$ & $998.3 \pm 7.1^{\mathrm{a}}$ & $1003.1 \pm 1.9^{\mathrm{a}}$ & $1006.7 \pm 7.7^{\mathrm{a}}$ & $1004.3 \pm 4.4^{\mathrm{a}}$ \\
\hline & 40 & $1005.9 \pm 2.3^{\mathrm{a}}$ & $1004.2 \pm 2.5^{\mathrm{a}}$ & $1002.8 \pm 3.2^{\mathrm{a}}$ & $1002.8 \pm 13.4^{\mathrm{a}}$ & $1002.8 \pm 5.7^{\mathrm{a}}$ \\
\hline & 50 & $1002.0 \pm 1.4^{\mathrm{a}}$ & $992.4 \pm 6.8^{\mathrm{a}}$ & $999.5 \pm 7.0^{\mathrm{a}}$ & $992.7 \pm 6.4^{\mathrm{a}}$ & $995.4 \pm 3.6^{\mathrm{a}}$ \\
\hline & 60 & $998.4 \pm 2.8^{a}$ & $995.6 \pm 2.6^{\mathrm{a}}$ & $993.5 \pm 7.5^{\mathrm{a}}$ & $988.7 \pm 6.5^{\mathrm{a}}$ & $992.0 \pm 3.2^{\mathrm{a}}$ \\
\hline \multirow{7}{*}{8} & 1 & $1019.8 \pm 4.4^{\mathrm{a}}$ & $1018.1 \pm 5.1^{\mathrm{a}}$ & $1005.2 \pm 17.2^{\mathrm{a}}$ & $1017.9 \pm 2.8^{a}$ & $1016.7 \pm 5.7^{\mathrm{a}}$ \\
\hline & 10 & $1010.8 \pm 11.9^{a}$ & $1017.4 \pm 2.0^{\mathrm{a}}$ & $1017.1 \pm 5.7^{\mathrm{a}}$ & $1016.7 \pm 5.4^{\mathrm{a}}$ & $1017.1 \pm 1.7^{\mathrm{a}}$ \\
\hline & 20 & $1017.5 \pm 5.2^{\mathrm{a}}$ & $1010.1 \pm 7.8^{a}$ & $1016.3 \pm 5.3^{a}$ & $1009.5 \pm 5.0^{\mathrm{a}}$ & $1015.3 \pm 0.4^{\mathrm{a}}$ \\
\hline & 30 & $1016.3 \pm 3.7^{\mathrm{a}}$ & $1013.9 \pm 0.9^{a}$ & $1013.8 \pm 6.9^{\mathrm{a}}$ & $1013.6 \pm 1.6^{\mathrm{a}}$ & $1007.6 \pm 5.0^{\mathrm{a}}$ \\
\hline & 40 & $1012.5 \pm 11.8^{a}$ & $1011.3 \pm 4.9^{\mathrm{a}}$ & $1010.6 \pm 1.1^{\mathrm{a}}$ & $1011.2 \pm 0.8^{\mathrm{a}}$ & $1010.6 \pm 0.2^{\mathrm{a}}$ \\
\hline & 50 & $1010.1 \pm 3.1^{\mathrm{a}}$ & $1008.7 \pm 4.3^{\mathrm{a}}$ & $1007.2 \pm 3.3^{\mathrm{a}}$ & $1008.1 \pm 4.2^{\mathrm{a}}$ & $1007.9 \pm 0.9^{\mathrm{a}}$ \\
\hline & 60 & $1006.2 \pm 1.9^{\mathrm{a}}$ & $1003.3 \pm 7.0^{\mathrm{a}}$ & $1003.2 \pm 2.6^{\mathrm{a}}$ & $1004.3 \pm 8.0^{\mathrm{a}}$ & $1003.6 \pm 1.4^{\mathrm{a}}$ \\
\hline \multirow{7}{*}{10} & 1 & $1022 \pm 3.8^{a}$ & $1022.6 \pm 7.9^{\mathrm{a}}$ & $1020.5 \pm 3.5^{\mathrm{a}}$ & $1017.6 \pm 9.0^{a}$ & $1015.4 \pm 10.2^{\mathrm{a}}$ \\
\hline & 10 & $1022.7 \pm 8.4^{\mathrm{a}}$ & $1022.3 \pm 1.9^{\mathrm{a}}$ & $1016.9 \pm 6.4^{\mathrm{a}}$ & $1017.1 \pm 6.1^{\mathrm{a}}$ & $1016.8 \pm 6.6^{\mathrm{a}}$ \\
\hline & 20 & $1022.7 \pm 1.8^{a}$ & $1019.8 \pm 5.2^{\mathrm{a}}$ & $1019.4 \pm 3.1^{\mathrm{a}}$ & $1015.7 \pm 6.4^{\mathrm{a}}$ & $1013.8 \pm 14.0^{a}$ \\
\hline & 30 & $1018.0 \pm 4.2^{\mathrm{a}}$ & $1013.7 \pm 7.3^{a}$ & $1017.6 \pm 3.0^{\mathrm{a}}$ & $1017.5 \pm 3.0^{a}$ & $1014.2 \pm 7.3^{\mathrm{a}}$ \\
\hline & 40 & $1018.0 \pm 2.0^{\mathrm{a}}$ & $1014.1 \pm 4.7^{\mathrm{a}}$ & $1013.8 \pm 4.2^{\mathrm{a}}$ & $1011.6 \pm 8.4^{\mathrm{a}}$ & $1010.9 \pm 12.3^{a}$ \\
\hline & 50 & $1016.1 \pm 5.3^{a}$ & $1010.4 \pm 4.2^{\mathrm{a}}$ & $1010.6 \pm 4.0^{\mathrm{a}}$ & $1007.9 \pm 6.5^{\mathrm{a}}$ & $1010.2 \pm 4.6^{\mathrm{a}}$ \\
\hline & 60 & $1010.4 \pm 4.5^{\mathrm{a}}$ & $1006.3 \pm 4.5^{\mathrm{a}}$ & $1009.3 \pm 4.0^{\mathrm{a}}$ & $1006.5 \pm 4.1^{\mathrm{a}}$ & $1006.1 \pm 4.7^{\mathrm{a}}$ \\
\hline \multirow{7}{*}{12} & 1 & $1036.5 \pm 3.6^{a}$ & $1030.7 \pm 7.9^{\mathrm{a}}$ & $1028.6 \pm 7.7^{\mathrm{a}}$ & $1025.6 \pm 6.2^{\mathrm{a}}$ & $1023.4 \pm 10.3^{a}$ \\
\hline & 10 & $1031.3 \pm 8.6^{a}$ & $1030.4 \pm 1.9^{\mathrm{a}}$ & $1024.9 \pm 8.9^{a}$ & $1025.1 \pm 6.6^{\mathrm{a}}$ & $1024.8 \pm 6.6^{\mathrm{a}}$ \\
\hline & 20 & $1033.1 \pm 1.3^{\mathrm{a}}$ & $1027.8 \pm 5.3^{\mathrm{a}}$ & $1027.4 \pm 4.0^{\mathrm{a}}$ & $1023.6 \pm 6.4^{\mathrm{a}}$ & $1021.7 \pm 13.6^{a}$ \\
\hline & 30 & $1030.4 \pm 1.8^{\mathrm{a}}$ & $1021.6 \pm 7.4^{\mathrm{a}}$ & $1025.6 \pm 7.2^{\mathrm{a}}$ & $1025.5 \pm 8.4^{\mathrm{a}}$ & $1022.2 \pm 6.0^{\mathrm{a}}$ \\
\hline & 40 & $1030.2 \pm 2.3^{\mathrm{a}}$ & $1022.1 \pm 4.7^{\mathrm{a}}$ & $1021.8 \pm 8.2^{\mathrm{a}}$ & $1019.6 \pm 6.2^{\mathrm{a}}$ & $1018.8 \pm 9.1^{\mathrm{a}}$ \\
\hline & 50 & $1025.7 \pm 4.5^{\mathrm{a}}$ & $1018.3 \pm 4.2^{\mathrm{a}}$ & $1018.6 \pm 4.1^{\mathrm{a}}$ & $1015.8 \pm 6.4^{a}$ & $1018.1 \pm 4.7^{\mathrm{a}}$ \\
\hline & 60 & $1023.1 \pm 2.5^{\mathrm{a}}$ & $1012.5 \pm 6.2^{\mathrm{a}}$ & $1017.2 \pm 4.0^{\mathrm{a}}$ & $1014.5 \pm 4.1^{\mathrm{a}}$ & $1014.1 \pm 5.1^{\mathrm{a}}$ \\
\hline
\end{tabular}

a,b,c Letters in the same line represent no significant difference at $95 \%$ of confidence interval by Tukey test.
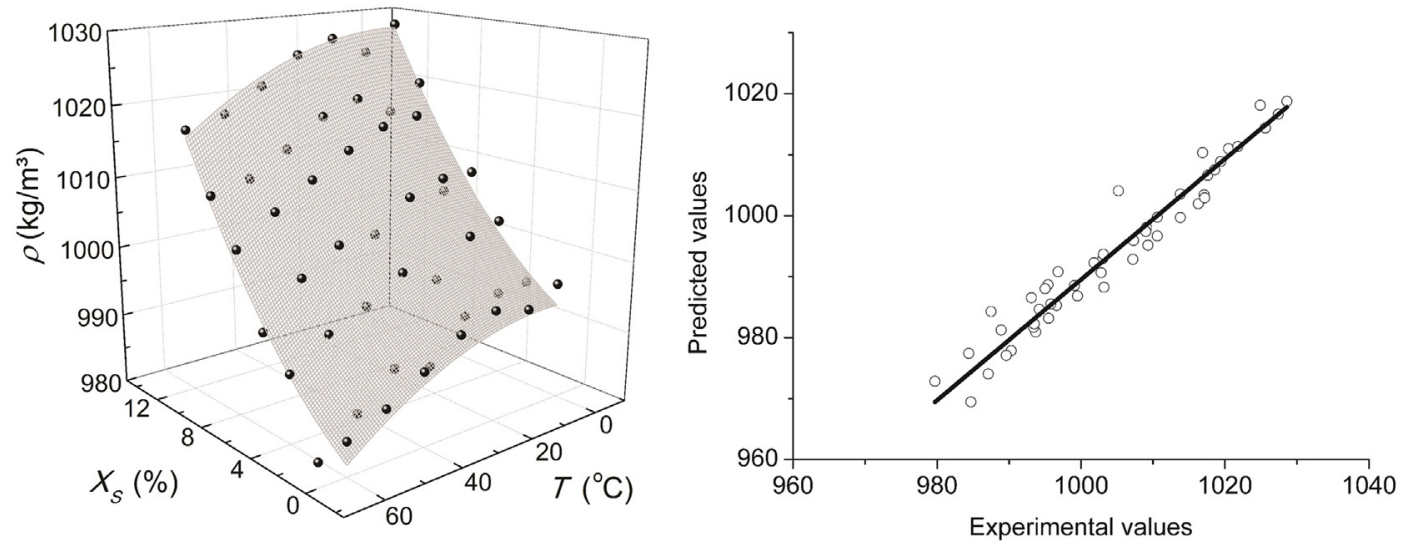

Fig. 7. Fitted surface of density values at pH 5.0 (left) and predicted values from the polynomial model versus the observed ones (right). 


\section{Conclusions}

The rheological properties and density of acidic suspensions of powder peanut shell were determined as function of solids concentration and temperature. A Newtonian behavior was found for suspensions up to $8 \%(w / w)$ of solids, and above this value, non-Newtonian characteristics were verified, including shear thinning and residual yield stress. In addition, the more concentrated suspensions seemed to be influenced by Farris effect, due to the large number of fine particles present in the material. At higher solids content, shear thinning was accompanied by increase in initial yield stress, consistency coefficient and density. As the $\mathrm{pH}$ did not present significant effects neither in rheological parameters nor in density, these properties could be represented solely as a function of temperature and solids concentration by the proposed models. These models are useful and will enable a basis for equipment and processes designing, mainly in those involving the lignocellulose conversion into biofuels.

\section{Acknowledgment}

Authors acknowledge the São Paulo Research Foundation, FAPESP (Grants 2013/09344-4 and 2013/17497-5) for financial support.

\section{References}

[1] R. Velmurugan, K. Muthukumar, Utilization of sugarcane bagasse for bioethanol production: sono-assisted acid hydrolysis approach, Bioresour. Technol. 102 (2011) 7119-7123.

[2] C.N. Hamelinck, G.v. Hooijdonk, A.P.C. Faaij, Ethanol from lignocellulosic biomass: techno-economic performance in short-, middle- and long-term, Biomass Bioenergy 28 (2005) 384-410.

[3] Y. Sun, J. Cheng, Hydrolysis of lignocellulosic materials for ethanol production: a review, Bioresour. Technol. 83 (2002) 1-11.

[4] A.M. Castro, N. Pereira-Jr, Production, properties and application of cellulases in the hydrolysis of agroindustrial residues, Quim. Nova 33 (2010) 181-188.

[5] O.P. Godoy, J. Marcos-Filho, G.M.S. Câmara, H. Fonseca, Tecnologia da produção, Amendoim: produção, pré-processamento e transformação agroindustrial, Secretaria da Indústria, Comércio, Ciência e Tecnologia, São Paulo, 1982.

[6] IBGE, Indicadores IBGE - Estatística da Produção Agrícola Ministério do Planejamento, Orçamento e Gestão, 201479.

[7] J. Araki, S. Kuga, Effect of trace electrolyte on liquid crystal type of cellulose microcrystals, Langmuir 17 (2001) 4493-4496.

[8] A. Esteghlalian, A.G. Hashimoto, J.J. Fenske, M.H. Penner, Modeling and optimization of the dilute-sulfuric-acid pretreatment of corn stover, poplar and switchgrass, Bioresour. Technol. 59 (1997) 129-136.

[9] Y.P. Wijaya, R.D.D. Putra, V.T. Widyaya, J.-M. Ha, D.J. Suh, C.S. Kim, Comparative study on two-step concentrated acid hydrolysis for the extraction of sugars from lignocellulosic biomass, Bioresour. Technol. 164 (2014) 221-231.

[10] P. Riedlberger, D. Weuster-Botz, New miniature stirred-tank bioreactors for parallel study of enzymatic biomass hydrolysis, Bioresour. Technol. 106 (2012) 138-146.

[11] J.F. Steffe, Rheological Methods in Food Process Engineering, second ed. Freeman Press, East Lansing, 1996.

[12] J.J. Stickel, J.S. Knutsen, M.W. Liberatore, W. Luu, D.W. Bousfield, D.J. Klingenberg, C.T. Scott, T.W. Root, M.R. Ehrhardt, T.O. Monz, Rheology measurements of a biomass slurry: an inter-laboratory study, Rheol. Acta 48 (2009) 1005-1015.

[13] J. Ferguson, Z. Kemblowski, Applied Fluid Rheology, Elsevier, New York, 1991.

[14] AOAC, Offical Methods of Analysis International, 16th ed. Association of Offical Analytical Chemists International, Gaithersburg, 1997.

[15] P.J. Van Soest, R.H. Wine, Use of detergents in the analysis of fibrous feeds. IV. Determination of plant cell-wall constituents, J. Assoc. Off. Anal. Chem. 50 (1967) 50-55.

[16] P.J. Van Soest, Use of detergents in the analysis of fibrous feeds. II. A rapid method for the determination of fiber and lignin, J. Assoc. Off. Agric. Chem. 43 (1963) 829-835.

[17] D.R. Lide, CRC Handbook of Chemistry and Physics, 74th ed. CRC, Boca Raton, 1993.
[18] ASTM, Annual Book of ASTM Standards, American Society for Testing and Materials, Philadelphia, 1989.

[19] S.D. Holdsworth, Rheological models used for the prediction of the flow properties of food products: a literature review, Food Bioprod. Process.: Trans. Inst. Chem. Eng. C 71 (1993) 139-179.

[20] M.A. Rao, Rheological properties of fluid foods, in: M.A. Rao, S.S.H. Rizvi (Eds.) Engineering Properties of Foods, Marcel Dekker Inc., New York 1986, pp. 1-47.

[21] R.d.C. Santana, A.C.K. Sato, R.L.d. Cunha, Emulsions stabilized by heat-treated collagen fibers, Food Hydrocoll. 26 (2012) 73-81.

[22] S. Haghighi Mood, A. Hossein Golfeshan, M. Tabatabaei, G. Salehi Jouzani, G.H. Najafi, M. Gholami, M. Ardjmand, Lignocellulosic biomass to bioethanol, a comprehensive review with a focus on pretreatment, Renew. Sust. Energ. Rev. 27 (2013) 77-93.

[23] D.-Q. Lin, L.-N. Zhong, S.-J. Yao, Zeta potential as a diagnostic tool to evaluate the biomass electrostatic adhesion during ion-exchange expanded bed application, Biotechnol. Bioeng. 95 (2006) 185-191.

[24] S. Elanthikkal, U. Gopalakrishnapanicker, S. Varghese, J.T. Guthrie, Cellulose microfibres produced from banana plant wastes: isolation and characterization, Carbohydr. Polym. 80 (2010) 852-859.

[25] B. Alince, A.A. Robertson, Aggregation of microcrystalline cellulose with polyethylenimine, Colloid Polym. Sci. 252 (1974) 920-927.

[26] L.H. Fasolin, R.L. Cunha, Characterisation of soy extract processed under different drying methods and extraction conditions, Int. J. Food Sci. Technol. 48 (2013) 503-511.

[27] L. Filippa, A. Trento, A.M. Álvarez, Sauter mean diameter determination for the fine fraction of suspended sediments using a LISST-25X diffractometer, Measurement 45 (2012) 364-368.

[28] L. Chen, Y. Duan, C. Zhao, L. Yang, Rheological behavior and wall slip of concentrated coal water slurry in pipe flows, Chem. Eng. Process. Process Intensif. 48 (2009) 1241-1248.

[29] H.-W. Lin, C.-P. Chang, W.-H. Hwu, M.-D. Ger, The rheological behaviors of screenprinting pastes, J. Mater. Process. Technol. 197 (2008) 284-291.

[30] T. Sato, Rheology of suspensions, J. Coatings Technol. 67 (1995) 69-79.

[31] M.A. Seka, W. Verstraete, Test for assessing shear sensitivity of activated sludge flocs: a feasibility study, Water Res. 37 (2003) 3327-3334.

[32] S.K. Sharma, M. LeMaguer, A. Liptay, V. Poysa, Effect of composition on the rheological properties of tomato thin pulp, Food Res. Int. 29 (1996) 175-179.

[33] S. Bhattacharya, Yield stress and time-dependent rheological properties of mango pulp, J. Food Sci. 64 (1999) 1029-1033.

[34] M. He, Y. Wang, E. Forssberg, Parameter studies on the rheology of limestone slurries, Int. J. Miner. Process. 78 (2006) 63-77.

[35] E.R. Bobicki, Q. Liu, Z. Xu, Effect of microwave pre-treatment on ultramafic nickel ore slurry rheology, Miner. Eng. 61 (2014) 97-104.

[36] S. Viamajala, J.D. McMillan, D.J. Schell, R.T. Elander, Rheology of corn stover slurries at high solids concentrations - effects of saccharification and particle size, Bioresour. Technol. 100 (2009) 925-934

[37] C. Chang, R.L. Powell, Effect of particle size distributions on the rheology of concentrated bimodal suspensions, J. Rheol. (1978-present) 38 (1994) 85-98.

[38] D.B. Genovese, J.E. Lozano, M.A. Rao, The rheology of colloidal and noncolloidal food dispersions, J. Food Sci. 72 (2007) R11-R20.

[39] J. MEWIS, C.W. MACOSCO, Suspension Rheology, in: C.W. MACOSCO (Ed.), Rheology: Principles, Measurements and Applications, VCH Publishers, New York 1993, pp. 425-474.

[40] M. Sepehr, P.J. Carreau, M. Moan, G. Ausias, Rheological properties of short fiber model suspensions, J. Rheol. (1978-present) 48 (2004) 1023-1048.

[41] T.-C. Nguyen, D. Anne-Archard, V. Coma, X. Cameleyre, E. Lombard, C. Binet, A Nouhen, K.A. To, L. Fillaudeau, In situ rheometry of concentrated cellulose fibre suspensions and relationships with enzymatic hydrolysis, Bioresour. Technol. 133 (2013) 563-572.

[42] G.P. Sheng, H.Q. Yu, X.Y. Li, Stability of sludge flocs under shear conditions: roles of extracellular polymeric substances (EPS), Biotechnol. Bioeng. 93 (2006) 1095-1102.

[43] V.P. Natarajan, G.J. Suppes, Rheological studies on a slurry biofuel to aid in evaluating its suitability as a fuel, Fuel 76 (1997) 1527-1535.

[44] R. Wang, J. Liu, F. Gao, J. Zhou, K. Cen, The slurrying properties of slurry fuels made of petroleum coke and petrochemical sludge, Fuel Process. Technol. 104 (2012) 57-66.

[45] C.G. Qiu, M.A. Rao, Role of pulp content and particle size in yield stress of apple sauce, J. Food Sci. 53 (1988) 1165-1170.

[46] R.J. Farris, Prediction of the viscosity of multimodal suspensions from unimodal viscosity data, Trans. Soc. Rheol. (1957-1977) 12 (1968) 281-301.

[47] H. Abdullah, D. Mourant, C.-Z. Li, H. Wu, Bioslurry as a fuel. 3. Fuel and rheologica properties of bioslurry prepared from the bio-oil and biochar of mallee biomass fast pyrolysis, Energy Fuel 24 (2010) 5669-5676. 